\title{
Analysis of Conflict Centers in Projects Procured with Traditional and Integrated Methods in Nigeria
}

\author{
Martin O. Dada \\ Senior Lecturer, Department of Building, University of Lagos, Lagos, Nigeria. E-mail: tobdad@yahoo.com
}

Project Management

Received February 3, 2012; received revisions April 7, 2012; May 16, 2012; accepted May 21, 2012

Available online June 15, 2012

\begin{abstract}
Conflicts in any organization can either be functional or dysfunctional and can contribute to or detract from the achievement of organizational or project objectives. This study investigated the frequency and intensity of conflicts, using five conflict centers, on projects executed with either the integrated or traditional method in Nigeria. Questionnaires were administered through purposive and snowballing techniques on 274 projects located in twelve states of Nigeria and Abuja. 94 usable responses were obtained. The collected data were subjected to both descriptive and inferential statistical analysis. In projects procured with traditional methods, conflicts relating to resources for project execution had the greatest frequency, while conflicts around project/client goals had the least frequency. For projects executed with integrated methods, conflicts due to administrative procedures were ranked highest while conflicts due to project/client goals were ranked least. Regarding seriousness of conflict, conflicts due to administrative procedures and resources for project execution were ranked highest respectively for projects procured with traditional and integrated methods. Additionally, in terms of seriousness, personality issues and project/client goals were the least sources of conflict in projects executed with traditional and integrated methods. There were no significant differences in the incidence of conflicts, using the selected conflict centers, between the traditional and integrated procurement methods. There was however significant difference in the intensity or seriousness of conflicts between projects executed with the traditional method and those executed with integrated methods in the following areas: technical issues, administrative matters and personality issues. The study recommends that conscious efforts should be made at teambuilding on projects executed with integrated methods.
\end{abstract}

Keywords: Conflict centers, integrated procurement, traditional procurement.

\section{Introduction}

A common feature of the construction industry is the fixity and immobility of its products with a contribution from participants who are varied and multidisciplinary (Ward, 1979; Adindu, 2003; Bamisile, 2004). The construction site remains a center of action and agglomeration of different individuals and participants with different objectives and loyalties. The construction project brings together individuals and/or organizations that are separate and disparate to form what has been termed a temporary multiorganization or a temporary project coalition (Murray et al, 1999; Rowlinson, 1999). Except in non- traditional procurement where participants on the construction projects can sometimes be under a single organization, the organizations for procuring the project are the client, contractor and consultants who are different commercial or professional entities. Even in the non-traditional procurement method, where the project participants can be in the same organizations, the interactions on the project can lead to conflicts. It thus implies that irrespective of organizational structures, conflict can occur, and conflicts do occur on construction projects. Whether the conflicts are between people, intra-organisational or interorganisational, conflicts remain a challenge in the construction industry (Kassab et al., 2010) with the potential to lead to lawsuits, project failures (Tsai and Chi, 2009), litigation and some times outright project abandonment (Yiu and Cheung, 2006; Tazelaar and Snijders, 2010). Such project abandonment and contract determination remain undesirable and costly features to a developing country such as Nigeria (Dada, 2004; Olateju, 1997)).

Procurement methods incorporate the organizational or legal/contractual arrangements of parties in the construction project to deliver the project. One of the issues that the procurement thus addresses is the organizational set-up or machinery for the project. Among those methods are the traditional method and the integrated methods. In the traditional procurement, there is an organisational/contractual separation of design from construction. Examples of the traditional procurement method are the lump-sum contract and labour-only contract. In integrated methods, design and construction are under a single contractual/organizational entity. A 
guiding principle is the single point responsibility for design and construction. Examples of integrated method are design-and-build, package deal and turnkey (Masterman, 1992). It is interesting to note that Ogunsanmi et al. (2011) reported a significant use of design-and-build method in project procurement in Nigeria. Other emerging procurement methods include private finance initiatives (PFIs) and public-privatepartnerships (PPPs) or their variants.

Generally, the construction industry has been reported as a harsh and tough industry due to pressures and competitiveness in the industry (Tazelaar and Snijders, 2010). The construction process is complex: the product is fixed while the process is flowing (Zhang and $\mathrm{Hu}, 2011$ ). Additionally, conflicts occur in all projects (Kassab et al, 2010). Tazelaar and Snijders (2010) found some evidence, though not extreme, that the construction industry has higher percentages of transactions (than in the information technology or general business -to-business transactions) leading to either arbitration, suspension of relationships or legal steps. Specifically, however, literature presentations suggest that the traditional method has a major weakness of adversarial and confrontational relationships, claim consciousness and participants' conflicting loyalties (Odeh and Battaineh, 2002; De-Valence and Houn, 1999; Fleming and Koppleman, 1997; Garza et al., 1994). The reported or perceived weaknesses in the traditional method and dissatisfaction with it have been a justification for stakeholders' recourse to other methods. The other methods, especially the integrated methods, are in principle assumed or supposed to overcome the weaknesses of the traditional method. Yet the traditional method remains the most dominant in the procurement of both public and private sector projects in some nations including Nigeria (Gordon, 1994; Ling et al., 2003; Nubi, 2003; Idoro et al., 2007). This research thus attempts an empirical investigation into how the traditional and integrated methods are faring on issues relating to conflicts: the incidence and intensity of conflicts in some specific areas relating to the project procurement. The research also seeks to identify and assess the conflict centers on projects executed with the two procurement methods. Furthermore, the research seeks to test the often held assertions regarding the performance of traditional and integrated procurement methods in relation to team or adversarial relationships. In the process, a contribution to the body of knowledge will have been made. Furthermore, there will be an objective basis to assess what obtains in real life in the research environment regarding conflicts in project procurement. Whether the image conferred on the traditional method regarding the incidence and intensity of conflicts (implied from adversarial, confrontational and legal relationships) is empirically true warrants this research. The research thus seeks to ascertain whether significant differences exist between the traditional and integrated projects on conflict performance.

\section{Theoretical Perspectives}

Conflict has been defined as any action or circumstance resulting from incompatible or opposing needs (Penamora et al., 2003 as cited in $\mathrm{Ng}$ et al., 2007). Conflict is an expressed struggle between at least two interdependent parties who perceive that incompatible goals, scarce resources, and interference from others are preventing them from achieving their goals (Wilmot and Hocker, 2001). Li et al. (2012) in a research indicated the possibility of conflicts arising on public projects from a mismatch between perceptions, expectations of stakeholders and reality

Jia et al. (2011) explored mega projects from the perspective of the social conflict theory. In their exploration of the theory of social conflict, they referred to Darhendof (2007) who discussed the functional effect of conflict on civilizations. Darhendof (2007) was reported to have claimed that conflict is the driving force for man's progress. From the social perspective, society means ruling, ruling means inequality, inequality brings conflict, and conflict constitutes a source of social progress, including the source of survival chance for the majority of people. Furthermore, conflict can be interpreted as a positive driver for social change or a positive response to change (Sportsman and Hamilton, 2007). The negative and undesirable effect of conflicts in the social sphere is manifested in wars. Functional conflicts challenge the status-quo and lead to further civilization.

Yiu and Cheung (2006) proposed a model, tested it and concluded that prevention is better than cure as far as construction conflict resolution is concerned. The model, which was later tested, indicates that conflict is positively correlated to the tension level among the project team. Their works distinguished between conflict and conflict behavior. To them conflict is one of the major influences on conflict behavior. A high conflict leads to a feeling of frustration that manifests as aggressive behavior. They referred to the study of Chen and Spector (1992) and other authors to show that the existence of conflict correlates with aggressive behavior. In the model, tension is assumed to affect conflict level. The intensity of tension tends to increase with the decrease in the social distance between groups and with the increase in the amount of energy behind them. In a project, tension may result from inconsistent demands from team members, identity crises, uncertainty or extra-organisational pressures. Incompatible groups sometimes as in the case of a team also increase tension. Time to deliver a project increases tension. Furthermore, behavioural flexibility was regarded as a splitting model. Flexible individuals will adjust (their conflict resolution styles) to a situation seeking to maximize potential collaboration to the benefit of all. The higher the behavioural flexibility of an individual, the better is their ability to positively respond in conflict situations. They concluded that a change in conflict level may turn into psychological struggles between contracting parties.

With respect to the construction industry, $\mathrm{Ng}$ et al. (2007) asserted that project conflicts can be described as a spiral between various parties in a design and construction project. $\mathrm{Ng}$ et al. (2007) developed a spiral of conflict. They argued that organizational issues or uncertainty in project initially cause the spiral. In essence, conflicts could arise from organisational issues that could arise from structure, process or people. Conflicts could also arise from uncertainty which is classified as either internal or external ( $\mathrm{Ng}$ et al., 2007). The external uncertainties include political risks, weather risks among others. Thamhain and Wilemon (1975) classified and categorized the causes of conflict in a project lifecycle to seven major sources: project priorities, administrative procedures, technical opinions and performance tradeoffs, manpower resources, costs, schedules and personality. Keszbom (1992) added six other sources of conflict to Thamhain 
and Wilemon's (1975) list. They include communication, reward, structure/performance appraisal, politics, leadership, ambiguous role/structure, and unresolved prior conflicts. Thamhain (1988) wrote on issues that had to do with conflict and interpersonal relations. Thamhain (1988) in his work asserted that interpersonal relations were an obvious and significant cause of conflict in all phases of project lifecycle.

In summary, the construction industry and organization in general is regarded to be harsh, competitive and conflict prone. Literature asserts that the some specific procurement methods have greater tendency to adversarial relationships (Odeh and Battaineh, 2002; De-Valence and Houn, 1999; Fleming and Koppleman, 1997; Garza et al., 1994). Furthermore, the areas or zones of conflict in a project revolve around organization and uncertainty, with organization including people, processes and structure. Uncertainty sometimes involves matters that relate to the external environment. In order to prevent or discontinue the spiral of conflict in construction project procurement, a first attempt at identification of the conflict centers in two selected procurement methods is necessary. There is a need to empirically test some of these literature assertions on projects procured with the traditional and integrated methods. There is also a need to investigate and rank the major zones of conflict in projects executed with the two procurement methods. The outcome of the investigation can then throw some light on the critical areas regarding intervention while not neglecting others. It could thus be a help in conflict/procurement management.

\section{Research Methods}

The research was conducted with the examination of relevant literature followed by field investigation. While the general classification of $\mathrm{Ng}$ et al. (2007) is on organizational issues and uncertainty, the current research attempts to group the internal sources of conflicts on projects to five major sources. This research distils from $\mathrm{Ng}$ et al. (2007) and Thamhain and Wilemon (1975) to arrive at the conflict centers used. The researcher used the people, process and structure concepts under organisational issues of $\mathrm{Ng}$ et al. (2007). This research also collapsed the resources and cost classification of Thamhain and Wilemon (1975) under 'Resources for project execution'. Furthermore, schedules were assumed in this study to be under administrative procedures. In essence, the research focused on the internal characteristics of the project especially with respect to procurement method. The research did not deal with external (environmental) sources of conflicts on the projects. The researcher deliberately isolated the external characteristics that could bring in some inconsistency in comparisons as the projects are located in different parts of Nigeria. Rather, the researcher focused on internal sources of conflict to enhance a comparison between the two procurement methods under investigation. The basis of comparisons remains the two procurement methods. As a result or in the process, the emphasis in the investigation is on the structure, resources and personality issues. The areas or zones where conflict can occur on the projects executed with the two procurement methods have been called 'conflict centers' in this research. Specifically, the conflict centers used in this investigation are: project/client goals, administrative procedures, technical issues, resources for project execution, and personality issues.
The data collection instrument used is a project specific questionnaire. It sought to know how an already executed/on-going project performed or was performing. It sought to know respondents' personal data. It also sought to obtain other data including project location, building or project type, size of building, number of floors of building, foundation type, client type, characteristics of design team, characteristics of construction team, nature of construction organization, client experience with respect to construction commissioning, client's business focus whether speculative or bespoke. Further biographical details judged relevant on the client, contractor, and consulting organizations were demanded. Thereafter, respondents were demanded to tick the procurement method used for the project. They were to further supply information on the method of tendering for the project. Additionally, they were requested to supply other project particulars of initial contract price or estimated total cost as appropriate. This was followed by the final contract price/anticipated final cost. Further data sourced included: year of award, initial or programmed contract duration, year of completion or projected year of completion, final contract duration and the total time of design and construction.

Respondents were asked to assess the frequency and seriousness of conflicts respectively in the selected conflict centers. The frequency of the conflict was measured on an ordinal scale of 1 for never, 2: rarely, 3: often, 4: always. The seriousness of conflict on the projects was measured and constructed in an ordinal manner thus: 4 : very serious; 3 serious; 2 is fairly serious; and 1 is for not serious.

Purposive and snowballing sampling techniques were used in data collection on projects being executed with the traditional and integrated methods. Respondents who were purposively identified by the researcher to have known or participated in any of the projects executed with either of the two procurement methods were contacted. They were thus required to distribute the questionnaire to other layer of contacts known by the first set of contacts. With this approach, data was obtained on projects located in twelve states of Nigeria and Abuja. The recourse to these nonprobabilistic techniques was due to the fact that there was no database of the number of projects being executed through the two methods. This line of reasoning was adopted in $\mathrm{Li}$ et al. (2005) who used convenience sampling due to lack of reliable database of the projects and subjects they were investigating. Furthermore the explanation of Kidder (1981) justified this method in that in some instances it is the only practicable and reliable way of getting required data. 274 copies of the prepared questionnaire were sent out to elicit responses on the projects under investigation. The questionnaires were administered on projects located in twelve states of Nigeria in addition to Abuja, the Federal Capital Territory. 97 completed questionnaires were received. 94 were adjudged usable by the researcher. The average response rate to the questionnaires was thus about $35 \%$, which is adjudged acceptable in view of researches in same field (Moser and Kalton, 1971 as cited by Mills and Skitmore, 1999; Li et al., 2005; Hoonakker et al., 2010). The response rate in this research is higher than the $29 \%$ and $12 \%$ respectively obtained by Hoonakker et al. (2010) and $\mathrm{Li}$ et al. (2005) which have been reported in construction and project management journals. The respondent on any of the projects could be a representative of any of the 
following organizations- client, contracting or consulting organizations. This was partly due to the impracticability of getting representatives of the three organizations on all projects especially the ones that had been completed at the time of questionnaire administration. Co-location of project participants on such projects had ended before administering the questionnaire. The level of significance for decision-making on the statistical analysis was set at $5 \%$.

\section{Analysis, Results and Discussion}

Some descriptive data generated from the project specific questionnaire are reported in this research. $54 \%$ of the projects were located in Lagos State while the remaining $46 \%$ were located in the eleven states including the Federal Capital Territory. Lagos houses the highest number of projects used for the study. One observation however is that projects were not necessarily located in the same state as that of the head office of the respondent organisation or the location of the official supplying the needed information. This is logical based on the line of reasoning that construction projects could be diverse from and dispersed from the head office. While construction projects are for most times immobile, project participants from whom respondents came consist of human beings who are highly mobile.

\subsection{Descriptive and Inferential Analysis}

Table 1 shows the projects used for the study based on the procurement method used.

$30(30.90 \%)$ of the projects were executed by integrated methods while $64(66.00 \%)$ were executed by traditional method. For the integrated procurement method (which has a response size of 30) however, design and build projects were $26(86.7 \%)$, package deal $1(3.33 \%)$ project, turnkey $1(3.33 \%)$ project while build operate transfer or variant were $2(6.67 \%)$.

Table 2 shows the client type for the respective projects. From Table 2, the client classification for the project shows that $32(33 \%)$ of the projects are owned or sponsored by private individuals, $29(29.9 \%)$ by private organizations, $32(33.0 \%)$ by public organizations, and $4(4.10 \%)$ by religious organizations.

Table 3 shows the purpose or intended use of building or development. $9(9.30 \%)$ of the projects were for industrial uses, $23(23.70 \%)$ commercial, $40(41.20) \%$ for residential, $19(19.60 \%)$ for institutional use while 6 $(6.20 \%)$ fall into the 'others' category.

The characteristics and composition of the design team are shown in Table $4.45(47.37 \%)$ of the projects were designed by in-house team, $32(33.69 \%)$ by external team while $18(18.94 \%)$ were designed by a mixed team.

Table 1. Projects and procurement methods used.

\begin{tabular}{ccc}
\hline Procurement method & Frequency & Percentage \\
\hline Integrated method & 30 & 30.90 \\
Traditional method & 64 & 66.00 \\
Not indicated & 3 & 3.10 \\
Total & 97 & 100.00 \\
\hline
\end{tabular}

Table 2. Client type for the respective projects.

\begin{tabular}{ccc}
\hline Client type & Frequency & Percentage \\
\hline Private individual & 32 & 33.00 \\
Private organization & 29 & 29.90 \\
Public sector & 32 & 33.00 \\
Religious organization & 4 & 4.10 \\
Total & 97 & 100.00 \\
\hline
\end{tabular}

Table 3. Purpose or intended use of building or development

\begin{tabular}{ccc}
\hline Use & Frequency & Percentage \\
\hline Industrial & 9 & 9.30 \\
Commercial & 23 & 23.70 \\
Residential & 40 & 41.20 \\
Public (institutional) & 19 & 19.60 \\
Others (e.g. religious) & 6 & 6.20 \\
Total & 97 & 100.00 \\
\hline
\end{tabular}


Table 5 shows the characteristics and composition of the construction team. $26(27.37 \%)$ of the projects were constructed/being constructed by in-house team, 48 $(50.52 \%)$ by external team while $21(22.11 \%)$ were designed by a mixed team. In-house team construction may translate to either of these options: the project is being constructed by direct labour or it was a design-andbuild project and its variant being constructed by the organization that has the contractual responsibility for design.

Table 6 shows the mean item scores of the frequency and ranks of conflict centers based on the two procurement methods.

Table 6 shows that in projects executed with the integrated methods, the first contributor to frequency of conflict is around administrative issue. The next conflict center is 'resources for project execution' which has a tie with 'personality issues'. 'Technical issues' relating to project execution was ranked fourth, while the least ranked conflict center is 'project/client goals'. In projects procured with the traditional method, the 'resources for project execution' was ranked as the most important conflict center. This was followed consecutively by 'administrative procedures', 'technical issues', 'personality issues' and then 'project/client goals'. The aggregated ranking for projects executed with the two procurement methods indicates that 'resources for project execution' was perceived to be the greatest conflict center or conflict zone. Issues on 'administrative procedures' ranked second. 'Technical issues' were ranked third while 'personality issues' were ranked fourth. The least issue in ranking is 'project/client goals'. The table has shown on the surface that the ranks of the two groups do not tally except for 'project/client goals'.

The next issue in the investigation is to find out if there are significant differences in the frequency of conflict around the identified conflict centers on projects executed with the traditional and integrated methods. To achieve this, the following null and alternative hypotheses were set up:

\section{- Null Hypothesis One $\left(\mathrm{Ho}_{1}\right)$}

There is no significant difference in the assessment of the frequency of conflict (around selected conflict centers) between projects executed through the traditional method and those executed through the integrated method.

\section{- Alternative Hypothesis One $\left(\mathrm{Hi}_{1}\right)$}

There is significant difference in the assessment of the frequency of conflict (around selected conflict centers) between projects executed through the traditional method and those executed through the integrated method.

The Mann Whitney analysis, a non parametric equivalent of the t-test, was used to test the above hypothesis on each of the conflict centers. Table 7 shows the results of the statistical test using the Mann Whitney analysis.

Table 4. Characteristics or composition of the design team for the projects

\begin{tabular}{ccc}
\hline Design team composition & Frequency & Percentage \\
\hline In-house team & 45 & 43.37 \\
Mixed team & 18 & 18.94 \\
External team & 32 & 33.69 \\
Total & 95 & 100.00 \\
\hline
\end{tabular}

Table 5. Characteristics and composition of the construction team

\begin{tabular}{ccc}
\hline Construction team composition & Frequency & Percentage \\
\hline In-house team & 26 & 27.37 \\
Mixed team & 48 & 50.52 \\
External team & 21 & 22.11 \\
Total & 95 & 100.00 \\
\hline
\end{tabular}

Table 6. Mean item scores and ranks of conflict centers based on frequency

\begin{tabular}{lcccccc}
\hline \multicolumn{1}{c}{ Conflict area } & $\begin{array}{c}\text { Mean } \\
\text { (Integrated) }\end{array}$ & $\begin{array}{c}\text { Rank } \\
\text { (Integrated) }\end{array}$ & $\begin{array}{c}\text { Mean } \\
\text { (Traditional) }\end{array}$ & $\begin{array}{c}\text { Rank } \\
\text { (Traditional) }\end{array}$ & $\begin{array}{c}\text { Mean } \\
\text { (Combined) }\end{array}$ & $\begin{array}{c}\text { Rank } \\
\text { (Combined) }\end{array}$ \\
\hline $\begin{array}{l}\text { Resources for project } \\
\text { execution }\end{array}$ & 2.23 & 2 & 2.32 & 1 & 2.28 & 1 \\
$\begin{array}{l}\text { Administrative } \\
\text { procedures }\end{array}$ & 2.37 & 1 & 2.14 & 2 & 2.23 & 2 \\
Technical issues & 2.20 & 4 & 2.11 & 3 & 2.15 & 3 \\
Personality issues & 2.23 & 2 & 2.02 & 4 & 2.09 & 4 \\
Project/client goals & 1.97 & 5 & 1.78 & 5 & 1.85 & 5 \\
\hline
\end{tabular}


Table 7 indicates that for all the conflict centers the significance value is greater than 0.05 , the set value for statistical significance. The implication is that the null hypothesis is accepted for all the conflict centers with respect to frequency of conflicts. This implies that there is no significant difference in the assessment of the frequency of conflict (around selected conflict centers) between projects executed through the traditional method and those executed through the integrated method.

It should be recalled from Table 6 that respondents did not assess that conflicts 'never' came up on the projects but rather 'rarely'. This comment is informed by the fact that the mean item scores on all the conflict centers approximate to '2' which implies 'rarely'. 'Never' has a value of ' 1 '. The next question or logical postulation is that even if conflicts do not come up frequently, the few ones that do may have varying intensity. One intense conflict may have more impact on a project and participants than many non-intense conflicts. This research thus sought to assess the seriousness of conflicts in those conflict centers in projects executed with the two procurement methods. In this regard the mean item scores of the seriousness of conflicts associated with those conflict centers in the respective procurement methods are indicated in Table 8 below.

An examination of the Table 8 indicates that in terms of degree of intensity or seriousness of conflicts, matters relating to 'resources for project execution' rank highest on projects executed with the integrated method. This was followed by 'technical issues', then administrative procedures. 'Personality issues' rank fourth, while the area ranked least was 'Project/client goals'. For projects executed with the traditional method, conflicts exhibit the greatest intensity on 'administrative matters'. This was followed by 'technical issues', then 'resources for project execution', then 'project/client goals'. Personality issues ranked least. Perhaps the rank that 'administrative matters' enjoy relating to seriousness of conflicts may be due to the fact that in traditional procurement, the parties are different legal and commercial entities each with differing goals and loyalties. The parties may be interested in how their interests will be protected in contract documentation and administration. The way the contract is administered, the formal relationships are all part of administrative matters. Table 8 just shows the relative rankings of the intensity or seriousness of conflicts in those conflict centers with respect to the procurement methods. It does not indicate whether any significant difference exists between the projects executed with the two procurement methods in matters of conflict. This leads us to a further test of hypothesis thus:

- Null Hypothesis Two $\left(\mathrm{Ho}_{2}\right)$

There is no significant difference in the assessment of the seriousness of conflicts (around selected conflict centers) between projects executed through the traditional method and those executed through the integrated method.

- Alternative Hypothesis Two $\left(\mathrm{Hi}_{2}\right)$

There is significant difference in the assessment of the seriousness of conflicts (around selected conflict centers) between projects executed through the traditional method and those executed through the integrated method.

Table 7. Mann Whitney-U analysis of test of differences on assessment of frequency of conflict

\begin{tabular}{lcccccccc}
\hline \multicolumn{1}{c}{ Conflict center (frequency) } & MRA & MRB & MSRA & MSRB & $\begin{array}{c}\text { MAN } \\
\text { N U }\end{array}$ & $\begin{array}{c}\text { Z } \\
\text { value }\end{array}$ & Sig. & Decision \\
& & & & & & \\
\hline Project/client goals & 51.72 & 45.52 & 1551.50 & 2913.50 & 833.50 & -1.099 & 0.272 & Accept $\mathrm{H}_{01}$ \\
Administrative procedures & 51.22 & 44.99 & 1536.50 & 2834.50 & 818.50 & -1.137 & 0.255 & Accept $\mathrm{H}_{01}$ \\
Technical issues & 47.73 & 46.65 & 1432.00 & 2939.00 & 923.00 & -0.190 & 0.850 & Accept $\mathrm{H}_{01}$ \\
Resources for project execution & 44.92 & 47.99 & 1347.50 & 3023.50 & 882.50 & -0.533 & 0.594 & Accept $\mathrm{H}_{01}$ \\
Personality issues & 51.35 & 44.93 & 1540.50 & 2830.50 & 814.50 & -1.128 & 0.259 & Accept $\mathrm{H}_{01}$ \\
\hline
\end{tabular}

$\mathrm{MRA}=$ Mean rank (Integrated); MRB= Mean rank (Traditional); MRSA= Mean sum of ranks (Integrated); MSRB = Mean sum of ranks (Traditional); Sig. = Significance

Table 8. Mean item scores and ranks of conflict centers based on seriousness

\begin{tabular}{lccccc}
\hline \multicolumn{1}{c}{ Conflict area } & $\begin{array}{c}\text { Mean } \\
\text { (Integrated) }\end{array}$ & $\begin{array}{c}\text { Rank } \\
\text { (Integrated) }\end{array}$ & $\begin{array}{c}\text { Mean } \\
\text { (Traditional) }\end{array}$ & $\begin{array}{c}\text { Rank } \\
\text { (Traditional) }\end{array}$ & $\begin{array}{c}\text { Mean } \\
\text { (Combined) }\end{array}$ \\
\hline $\begin{array}{l}\text { Resources for } \\
\text { project execution }\end{array}$ & 2.40 & 1 & 1.52 & 3 & 1.83 \\
$\begin{array}{l}\text { Administrative } \\
\text { procedures }\end{array}$ & 2.07 & 3 & 1.73 & 1 & 1.82 \\
Technical issues & 2.17 & 2 & 1.57 & 2 & 1.77 \\
Personality issues & 1.93 & 4 & 1.33 & 5 & 1.56 \\
Project/client goals & 1.87 & 5 & 1.38 & 4 & 1.55 \\
\hline
\end{tabular}


Table 9 shows the results of the analysis of the test of differences on assessment of seriousness of conflicts.

For significance values (or p-values) above 0.50 , the decision is to accept the null hypothesis. For values less than 0.05 , the null hypothesis is rejected. Table 9 indicates that in matters of the seriousness of conflicts due to 'project/client goals' there is no significant difference between projects executed with the integrated method and with the traditional method. The same conclusion holds for 'administrative matters'. However, significant differences exist between projects executed with the two methods regarding the seriousness of conflicts on matters connected to 'Technical issues', 'Resources for project execution' and 'Personality issues.'

\subsection{Discussion}

The results from the analysis are illuminating. While the mean item scores for the incidences or frequency of conflicts in the identified zones differ sometimes from each other, the statistical analysis leads to the conclusion that no significant differences exist between the traditional and integrated methods in projects executed through them. Furthermore, while Table 6 shows the relative rankings based on the mean item scores of the conflict centers, a further examination of the table indicates that the mean item scores hover around and approximate to ' 2 '. In the definition of this research, '2' implies an assessment of 'rarely frequent'. This suggests that the average response for each category (for integrated method and traditional method) is that conflicts rarely exist. This brings to fore some fundamental issues. Anecdotal evidence or literature postulation is that the traditional procurement method is more prone to adversarial or confrontational relationships than the integrated method. Additionally, an examination of Table 8 suggests that the mean item scores of the seriousness of conflicts on personality issues is greater in projects executed with integrated methods than in projects executed with traditional methods. The inferential statistics indicate that on the same issue, there are significant differences. This implies that conflicts in integrated projects are more serious than in the projects executed with the traditional method. This result raises some fundamental issues. The result is contrary to the position taken in literature indicating that the traditional method is more adversarial than the traditional method. Perhaps one possible rationalization is that relationships or formalization of procedures might have been taken for granted or neglected in the integrated method. In the end, unintended results 'may have followed indicating more serious conflicts in integrated methods than in the traditional. This research outcome seems to support Errikson (2008) who concluded in his findings on matters relating to the procurement process, that there exist differences between expectations, desired outcome and reality. That while some parties desire some good outcomes, they are not consciously working towards it. Another implication of this finding is that it is not just enough to procure projects based on often held opinions of which procurement performs better without putting in place adequate structures. Assumptions of success through a particular procurement method may not be always valid. (Underlying conditions and enabling environment must exist). This implication tallies with the conclusion of Sarmento (2010), who on PPP, says that there should be no prejudiced belief - positive or negative - regarding approach to and value of the procurement path. Rather decisions should be made on sound analysis of its worth and costs. In this present research, one implication from the assessment of seriousness of conflicts due to personality issues is that conscious efforts at team building must be geared towards the use of integrated methods. Another issue thrown up in the research is that while the first test is on the frequency of conflicts, the next test is on the intensity. While there are no significant differences between the two methods, there are significant differences between the two methods regarding seriousness of conflicts in some conflict centers. This thus raises the question: what is the relationship generally between the frequency or incidences of conflicts and the seriousness (intensity of conflicts)? Specifically, what is the relationship between frequency and seriousness of conflicts in the conflict centers of: technical issues, administrative matters and personality issues in project procurement? These questions remain the subject of future investigation. Which constructs are construction management researchers using when they are referring to adversarial relationships in project procurement? Is it in the frequency? Is it in the seriousness? Is one a cause of the other or is it a spiral?

Table 9. Mann Whitney-U analysis of test of differences on assessment of seriousness of conflicts

\begin{tabular}{|c|c|c|c|c|c|c|c|c|}
\hline Conflict center & MRA & MRB & MSRA & MSRB & $\begin{array}{c}\text { MAN } \\
\text { N U }\end{array}$ & $\begin{array}{c}\mathrm{Z} \\
\text { value }\end{array}$ & Sig. & Decision \\
\hline Project/client goals & 52.83 & 44.22 & 1585.00 & 2786.00 & 770.00 & -1.658 & .097 & Accept $\mathrm{HO}_{2}$ \\
\hline Administrative procedures & 52.18 & 44.53 & 1565.50 & 2805.50 & 789.50 & -1.342 & .180 & Accept $\mathrm{HO}_{2}$ \\
\hline Technical issues & 56.00 & 42.71 & 1680.00 & 2691.00 & 675.00 & -2.334 & .020 & Reject $\mathrm{HO}_{2}$ \\
\hline Resources for project execution & 58.78 & 41.39 & 1763.50 & 2607.50 & 591.50 & -3.072 & .002 & Reject $\mathrm{HO}_{2}$ \\
\hline Personality issues & 55.30 & 43.05 & 1659.00 & 2712.00 & 696.00 & -2.261 & .024 & Reject $\mathrm{HO}_{2}$ \\
\hline
\end{tabular}




\section{Conclusions and Recommendations}

The study investigated the frequency and seriousness of conflicts on projects investigated with traditional and integrated procurement methods. In projects procured with traditional methods, the order of occurrence of conflicts around the conflict centers is: Resources for project execution, Administrative procedures, Technical issues, Personality issues, Project/client goals. Conflicts due to matters of Resources for project execution had the greatest frequency, while conflicts around Project/client goals had the least frequency. For integrated methods the corresponding order is: Administrative procedures, Resources for project execution/Personality issues (the two factors tie), Technical issues,, and Project/client goals. Regarding seriousness or intensity of conflicts, the traditional method exhibits the order: Administrative procedures, Technical issues, Resources for project execution, Project/client goals, and Personality issues. Administrative procedures were ranked highest while Personality issues were ranked least. The corresponding order for integrated methods is: Resources for project execution, Technical issues, Administrative procedures, Personality issues, and Project/client goals. There were no significant differences between the frequency of conflicts on projects executed with the traditional method and the integrated methods. There were however significant differences in the seriousness or intensity of conflicts between projects executed with the traditional and integrated methods in the following centers conflict: technical issues, administrative matters and personality issues. Some of the research findings do not tally with opinions expressed in literature regarding the traditional procurement method. Seriousness of conflicts along personality issues is greater in projects executed with integrated methods than in projects executed with traditional method. The rationalization might be that the affected organizations may have been complacent assuming things will automatically work based on their organisational structure. An implication of this finding is that it is not just enough to procure projects based on often held opinions of which procurement performs better without putting in place adequate structures. The extended implication is that the name and perceived advantages of integrated method regarding teambuilding will not just automatically manifest without conscious efforts. Another implication of the study is that while there are no significant differences in the three areas with respect to frequency of conflicts on projects executed with the two procurement methods, there are differences with respect to seriousness of conflict in the three conflict centers. This thus calls for further investigation of empirical relationship between the frequency or incidence of conflicts and the seriousness or intensity of conflicts in general and in particular on those conflict centers in construction project procurement. It is recommended that conscious efforts should be made at teambuilding on projects executed with integrated methods.

\section{References}

Adindu, G. O. (2003). The construction engineer and social responsibility. Paper presented at Global 2003The 1st International Conference on Globalisation and Capacity Building for the Construction Industry of Developing Economies, University of Lagos, Lagos.

Bamisile, A. (2004). Building production management. Lagos: Foresight Press Ltd.
Chen, P.Y., Spector, P.E. (1992). Relationship of work stereos with aggression, withdrawal, theft and substance abuse: An exploratory study. Journal of occupational and organizational psychology, 65, 177184.

Dada, M.O. (2004). Teambuilding procurement methods, selection and project performance in some states in Nigeria, Unpublished $P h D$ Thesis submitted to the School of Post-graduate Studies, University of Lagos, Lagos.

Darhendof, R. (2007). The modern social conflict: The politics of liberty. Second edition, New Jersey: Transactions Publishers.

De-Valence, G., Houn, N. (1999). Procurement strategies. In Best, $\mathrm{R}$ and De-Valence, G. Building in value. Australia: Arnold and the Contributors.

Erikkson, P.E. (2008). Procurement effects on coopetition on client contractor relationships. Journal of construction Engineering and Management, 134(2), 103-111.

Flemming, Q.W., Koppleman, J.M. (1997). Integrated project development teams: Another fad or... a permanent change. Project Management Journal, 28(1), 4-11.

Garza, J.M., Alcantara, P., Kapoor, M., Ramesh, P.S. (1994).Value of concurrent engineering for AEC industry. Journal of Management in Engineering, 10(3), 46-55.

Gordon, C.M. (1994). Choosing appropriate construction contracting method. Journal of Construction Engineering and Management, 120(1), 196-210.

Hoonakker, P., Carayon, P., Loushine, T. (2010). Barriers and benefits of quality management in the construction industry: An empirical study. Total Quality Management, 21(9), 953-969.

Idoro, G.I., Iyagba, R.O.A., Odusami, K.T. (2007). Evaluation of the use of design-bid-build procurement system in the Nigerian construction industry. Construction Research Journal, 1(1), 15-25.

Jia, G., Yang, F., Wang, G., Hong, B., You, R. (2011). A study of mega project from a perspective of social conflict theory. International Journal of Project Management, 29, 817-827.

Kassab, M., Hegazy, T., Hipel, K. (2010). Computerised DSS for construction conflict resolution under uncertainty. Journal of Construction Engineering and Management, 136(12),1249-1257.

Keszbom, D.S. (1992). Reopening Pandora's box: Sources of project conflicts in the 90s. Industrial Engineering (USA), 24(5), 54-59.

Kidder, L.H. (1981). Seltiz, Wrightsman and Cook's Research Methods in Social Relations. Japan: Holt, Rinehart and Winston.

Li, B., Akintoye, A., Edwards, P.J., Hardcastle, C. (2005). Critical success factors for PPP/PFI projects in the UK construction industry. Construction Management and Economics, 23, 459-471.

Li, T.H.Y., Ng, S.T., Skitmore, M. (2012). Conflicts or consensus: An investigation of stakeholder concerns during the participation process of major infrastructure and construction projects in Hong Kong. Habitat International, 36, 333-342.

Ling, Y. N., Ofori, G., Low, S. P. (2003). Evaluation and selection of consultants for design-build projects. Project Management Journal, 34(1), 12-22.

Masterman, J.W.E. (1992). Introduction to procurement systems. London: E \& FN Spon Ltd. 
Mills, A., Skitmore, M. (1999). A comparison of client and contractor attitudes to pre-qualification criteria. In S. O. Ogunlana (Ed.) Profitable partnering in construction procurement, 699-708. London: E \& FN Spon Limited.

Murray, M., Langford, D., Hardcastle, C., Tookey, J. (1999). Organisational design. In S. Rowlinson., P. McDermott (Eds.) Procurement systems: A guide to best practice in construction, 83-118. London: E \& FN Spon Ltd.

Ng, H.S., Pena-mora, F., Tamaki, T. (2007). Dynamic conflict management in large-scale design and construction projects. Journal of Management in Engineering, 23(2), 252-266.

Nubi, T.O. (2003).Construction procurement: Need for paradigm shift. Building Quarterly, 1(10), 17-27.

Odeh, A.M., Battaineh, H.T. (2002). Causes of construction delay: Traditional contracts. International Journal of Project Management, 20(1), 67-73.

Ogunsanmi, O.E., Salako, O.A., Ajayi, O.A. (2011). Risk classification model for design-and-build projects. Journal of Engineering, Project and Production Management, 1(1), 46-60.

Olateju, B. (1997). Report on abandoned projects. Paper presented at a national seminar organized by The Nigerian Institute of Building and Council of Registered Builders of Nigeria on consultancy practice for professional builders, Abuja.

Rowlinson, S. (1999). Selection criteria. In S. Rowlinson., P. McDermott (Eds.) Procurement systems: A guide to best practice in construction, 276-299. London: E \& FN Spon Ltd.

Sarmento, J.M. (2010). Do PPPs create value for money for the public sector? The Portuguese experience. OECD Journal on Budgeting, 93-119.

Sportsman, S., Hamilton, P. (2007). Conflict management styles in health professions. Journal of professional nursing, 23(3), 157-166.

Tazelaar, F., Snijders, C. (2010). Dispute resolution and litigation in the construction industry: Evidence on conflicts and conflict resolution in the Netherlands and Germany. Journal of Purchasing and Supply Chain Management, 16, 221-229.

Thamhain, H. J., Wilemon, D. L. (1975). Diagnosing conflict determinants in project management. IEEE Transactions on Engineering Management, 22(1), 3544.

Thamhain, H. J. (1988). Team building in project management. In D. I. Cleland., \& W.R. King. (Eds.)
Project management handbook, 823-846. New York: Van Nonstrand Reinhard.

Tsai, J., Chi, C. S. F. (2009). Influences of Chinese cultural orientations and conflict management styles on construction dispute resolving strategies. Journal of construction engineering and management, 135(10), 955-964.

Ward, P. A., (1979). Organization and procedures in the construction industry. Great Britain: Mac Donald and Evans Ltd.

Wilmot, W., Hocker, J. (2001). Interpersonal conflict $6^{\text {th }}$ edition. Boston: McGraw HillYiu, K.T.W., Cheung, S.O. (2006). A catastrophe model of construction and conflict behavior. Building and Environment, 41, 438447.

Yousefi, S., Hipel, K., Hegazy, T. (2010). Attitude based strategic negotiation for conflict management in construction projects. Project Management Journal September, 99-107.

Zhang, J.P., Hu, Z. Z. (2011). BIM and 4D-based integrated solution of analysis and management of conflicts and structural safety problems during construction: Principles and methodologies. Automation in Construction, 20, 155-166.

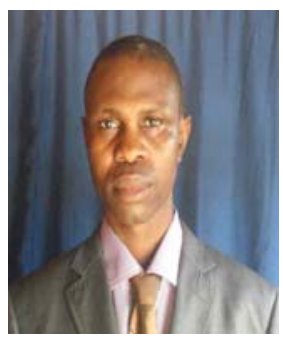

Dr. Martin. O. Dada is a Senior Lecturer in the Department of Building at the University of Lagos, Lagos, Nigeria. He obtained his Bachelor of Science degrees in Building in 1987 from former University of Ife (now Obafemi Awolowo University), Ile-Ife, Nigeria. He bagged his MSc and $\mathrm{PhD}$ degree in Construction Management in 1990 and 2004 respectively from University of Lagos, Nigeria. He has had varied experience in the production and project management of large and complex residential, institutional, commercial and industrial projects in both contracting and consulting capacities. He is a member of the Nigerian Institute of Building and he is also registered by the Council of Registered Builders of Nigeria. His research interests span project procurement, concurrent engineering, human resource management and sustainability issues. 


\section{Extract From Questionnaire}

\section{RESPONDENT'S PERSONAL DATA}

1. Profession (tick as appropriate)

(a) Civil Engineer (b) Land surveyor (c) Builder (d) Mechanical Engineer (e) Architect (f) Electrical Engineer (g) Quantity Surveyor (h) Estate Surveyor (i) Combination of one or more of the above (j) others ( Please specify).......

2. Number of years of experience

(a) $\geq 15$ years (b) $\geq 12<15$ years (c) $\geq 8<12$ years (d) $\geq 4<8$ years (e) $<4$ years

3. Highest Educational qualification

(a) West African School Certificate (b) National Diploma or equivalent (c) Higher National Diploma (d) Bachelors (e) Masters (f) PhD (g) Others (please specify).

4. Age of respondent (in years)

(a) 21-30 (b) 21-30 (c) 31-40 (d) 51-65 (e) $>65$

5. State of residence or location.

\section{PROJECT PARTICULARS}

5. In what capacity are you reporting or did you operate on the project?
(a) Client's representative
(b) Consultant's representative
(c) Contractor's representative
(d) Others (please specify).

6. Project location.

7. Client type for the project:

(a) Bespoke: client builds for her own use

(b) Speculative- client builds houses for sale

8. What is the building or project type?
(a) Industrial
(b) Commercial
(c) Residential
(d) Public/institutional
(e) Others (e.g. religious)

9. Characteristics of design team: design done by:
(a) In-house team
(b) External team or organization
(c) Mixed team (in-house and external)

10. Characteristics of construction team: construction done by:
(a) In-house team
(b) External team or organization
(c) Mixed team (in-house and external)

11. What is the size or gross floor area of the building?
(a) Less than 3000 square meters
(b) $3000-10,000$ square meters
(c) Greater than 10,000 square meters

12. Kindly indicate the approximate plan dimensions (in meters).

13. Number of floors of the building 
76 Martin O. Dada
(a) Bungalow
(b) 1-2 floors
(c) 3-4 floors
(d) Above 4 floors

14. Please indicate the client type for the project
(a) Private individual
(b) Private organization
(c) Public sector
(d) Social clubs
(e) Religious organization

15. Kindly tick client's experience in construction commissioning
(a) Commissions at least one project once every one year
(b) Commissions at least one project once every three years
(c) Commissions at least one project once every five years
(d) This is the first project for the client

16. What was the project procurement/delivery method? (i.e. method of getting the project executed from design to construction commissioning/completion)

(a) Traditional method (e.g. labour only contract, full lump-sum contract)

(b) Integrated method (design and construction done under a single organizational/contractual entity) e.g.

(i) Design-and-build

(ii) Turnkey: design, construction, financing by the organisation

(iii) Package deal: design, construction, financing and property management

(iv) Build-operate-transfer or any of its variants

(c) Others (please specify under the appropriate answer/group)

17. Supply original or planned total contract/project cost in naira....

18. Supply final or anticipated contract/project cost in naira.

19. Supply initial/programmed contract duration (in months).

20. Supply final/anticipated final contract duration (in months).

21. Total time of design and construction (in months)

\section{FREQUENCY AND SERIOUSNESS OF CONFLICTS}

22. On a scale of 1- 4 (1 for never, 2: rarely, 3: often, 4: always), assess the frequency of conflicts (if any) on the project in the areas indicated below:
(a) Resources for project execution
(b) Administrative procedures
(c) Technical issues
(d) Personality issues
(e) Project/client goals

23. On a scale of 1- 4 ( 1 for not serious, 2: fairly serious, 3: serious, 4: very serious) assess the seriousness of conflicts in question 22 above (if any) on the project in the areas indicated below:
(a) Resources for project execution
(b) Administrative procedures 

(c) Technical issues
(d) Personality issues
(e) Project/client goals 